\title{
Tingkat Motivasi Dan Model Aktivitas Jasmani Siswa Dan Guru SMAN 2 Sumenep Di Masa Pandemi
}

\author{
${ }^{1}$ Ismail Marzuki Bhetharem, ${ }^{2}$ I Made Sri Undy Mahardika, ${ }^{3}$ Abdul Rachman Syam Tuasikal \\ ${ }^{1}$ Program Studi Pendidikan Olahraga, Pascasarjana Universitas Negeri Surabaya, Jawa Timur, \\ Indonesia \\ ${ }^{23}$ Fakultas Ilmu Keolahragaan, Universitas Negeri Surabaya, Jawa Timur, Indonesia \\ Email: ismail.17070805022@mhs.unesa.ac.id ${ }^{1}$, imadesriundy@yahoo.co.id ${ }^{2}$,
} rachmantuasikal@unesa.ac.id ${ }^{3}$

\begin{abstract}
This thesis discusses motivation level and physical activity for students and teachers during pandemic period in SMAN 2 Sumenep. This study aims to view the motivation level of the students in following various learning models of Physical Education and the various learning models of Physical Education during pandemic. Quantitative descriptive with survey method is applied. Google Forms had been shared to 288 students consist of grade X, XI, and XII. The result study shows that their motivation level is in the medium category, as specifically 143 students (49,7\%). Meanwhile, the physical activity models for students and teachers has been taught through free online applications such as Google Class Room, YouTube, Vidio Zoom, WhatsApp and Telegram. The next result shows that Google Class Room is the most options with 150 respondents $(52,1 \%)$.
\end{abstract}

Keywords: Motivation, Physical Activity, Pandemic

\begin{abstract}
Abstrak
Penelitian ini adalah penelitian deskriptif kuantitatif, metode yang digunakan dalam penelitian ini adalah metode survei. Instrumen dalam penelitian ini yaitu dengan menggunakan angket yang dibagikan secara on-line melalui google form dengan jumlah sampel sebanyak 288 siswa SMAN 2 Sumenep yang terdiri dari siswa kelas X, XI dan XII. Penelitian ini bertujuan untuk mengetahui tingkat motivasi siswa dalam mengikuti pembelajaran PJOK dan model aktivitas jasmani siswa dan guru SMAN 2 Sumenep di masa pandemi. Data hasil penelitian yang diperoleh bahwa tingkat motivasi siswa dalam mengikuti pembelajaran PJOK dimasa pandemi berada pada kategori sedang yaitu sebanyak 143 (49,7\%) siswa, sedangkan pada model aktivitas jasmani siswa dan guru SMAN 2 Sumenep dimasa pandemi dilakukan dengan melalui Applikasi gratis seperti google classroom, YouTube, Vidio Zoom, WhatsApp serta Telegram. Namun opsi jawaban paling banyak bahwa selama pandemi aktivitas jasmani sering dilakukan dengan mengerjakan latihan soal melalui google classroom yaitu dengan jumlah responden $150(52,1 \%)$.
\end{abstract}

Kata Kunci: Motivasi, Model Aktivitas Jasmani, pandemi

\section{PENDAHULUAN}

Sejak tanggal 16 Maret 2020 siswa mulai melakukan pembelajaran secara on-line, diminggu pertama siswa mengikuti dengan penuh semangat, tugas yang diberikan guru melalui sebuah applikasi WhatsApp (WA) mereka kerjakan dengan baik dan penuh dengan semangat, dan hampir dua bulan siswa harus mengikuti pembelajaran secara daring tentunya akan ada dampak tersendiri bagi para siswa. Kemungkinan semangat mereka sudah tidak lagi seperti minggu pertama, dan pada akhirnya eksistensi pembelajaran yang menyenangkan akhirnya menjadi pembelajaran yang membosankan. Dalam pembelajaran on-line ternyata para siswa bisa menjadi sangat kurang aktif dalam belajar dan dalam menyampaikan aspirasinya berupa pemikirannya, sehingga akan mengakibatkan suasana pembelajaran yang menjenuhkan atau membosankan (Ferismayanti, 2020). 
Jika pada kenyataannya di masa pandemi aktivitas pembelajaran yang dilakukan dari rumah membuat siswa menjadi jenuh dikarenakan aktivitas mereka monoton yaitu hanya mengerjakan tugas latihan yang diberikan oleh guru, maka dari itu tidak dapat dipungkiri bahwa sebenarnya tingkat motivasi belajar siswa menjadi menurun akibat efektivitas pembelajaran yang monoton. "motivation greatly influences an individual's performance in situations where one is physically capable of performing the task but is uncertain about capabilities, which in many cases is a problem that driver people not to begi with a chosen sports activity" (Kodri et al., 2013:10)

Bagi guru dan sekolah yang sudah terbiasa melaksanakan pembelajaran secara on-line tentu bukan menjadi suatu masalah, menyikapi permasalah tersebut tentunya guru dan sekolah telah menerapkan berbagai strategi yang beragam dan tentunya bukan berarti tanpa kendala. Selain itu, pada saat ini juga dikeluhkan oleh para orangtua bahwa saat mendampingi siswa belajar di rumah merupakan beban tersendiri bagi orangtua yang tidak memiliki latar belakang pendidikan yang cukup. Efektivitas pembelajaran PJOK yang dilakukan secara on-line di masa pandemi covid-19 ternyata berjalan secara efektif, dan aplikasi yang paling mudah digunakan oleh siswa adalah Google Classroom (Purnama and Sutupa, 2020).

Berdasarkan wawancara yang dilakukan oleh peneliti kepada guru PJOK di SMAN 2 Sumenep yaitu menggunakan aplikasi Google Classroom, YouTube, WhatsApp dan Telegram sebagai medianya. Alasannya aplikasi ini dianggap sederhana dan mudah digunakan oleh para siswa. Dari semua penjelasan di atas dapat diambil kesimpulan bahwa pola pembelajaran jarak jauh yang pelaksananaya secara on-line pastinya memiliki tantangan tersendiri bagi guru PJOK dan juga siswa yang biasanya aktivitas pembelajaran lebih dominan dilakukan di luar ruangan atau di lapangan olahraga, dimana saat ini harus dilaksanakan di rumah secara mandiri. Maka dari itu dalam hal ini peneliti tertarik untuk mengadakan penelitian dengan judul Tingkat Motivasi dan Model Kegiatan
Aktivitas Jasmani Siswa dan Guru SMAN 2 Sumenep di Masa Pandemi.

\section{METODE}

Penelitian ini adalah penelitian deskriptif kuantitatif, Metode yang digunakan dalam penelitian ini yaitu dengan menggunakan metode survei. "Penelitian survei adalah penelitian yang mengambil sampel dari populasi dan menggunakan kuesioner sebagai alat pengumpul data yang pokok" (Sriundy, 2015:93). Teknik sampel dalam penelitian ini mengunakan proportionate stratified random sampling dikarenakan populasi sampel dalam penelitian mempunyai strata atau tingkatan yaitu kelas X, XI dan XII. Pengambilan sampel jika subjeknya kurang dari 100 maka lebih baik diambil semua, namun jika subjeknya lebih dari 100 maka sampel yang diambil antara 10$15 \%$ atau $20-25 \%$ atau lebih (Suharsimi, 2002). Dikarenakan jumlah populasi lebih dari 100 siswa maka peneliti mengambil sampel masing-masing kelas sebanyak 26\% dari jumlah populasi, yaitu kelas X sebanyak 103 dari 399 siswa, kelas XI 79 dari 306 siswa dan kelas XII 106 dari 410 siswa dengan total keseluruhan sampel menjadi 288 siswa. Teknik pengumpulan data dalam penelitian ini menggunakan angket (google form) yang disebar melalui grub WA. Sedangkan Teknk analisis dalam penelitian ini yaitu dianalisis secara deskriptif menggunakan SPSS.16 untuk melihat kecenderungan yang terjadi dalam proses pembelajaran PJOK di masa pandemi.

\section{HASIL}

\section{Tingkat motivasi siswa dalam mengikuti pembelajaran PJOK}

Pada penelitian ini, tingkat motivasi mengikuti pembelajaran PJOK yang dilakukan secara online dijabarkan ke dalam 10 aitem pernyataan dengan skor $1 \mathrm{~s} / \mathrm{d} 4$ sehingga diperoleh hasil skor minimum ideal yaitu 1 x 10 sebesar 10, dan skor maksimum ideal yaitu 4 x 10 sebesar 40. Selanjutnya hasil skor maksimum dikurangi skor minimum kemudian hasilnya dibagi 5 kategori:

$\frac{40-10}{5}=\frac{30}{5}=$ sehingga di peroleh panjang kelas interval yaitu 6 dengan banyak kelas yaitu 5 . 
Tabel 1. Kategori Tingkat Motivasi Siswa Mengikuti Pembelajaran PJOK di SMAN 2 Sumenep

\begin{tabular}{cccc}
\hline Interval Skor & $\mathbf{F}$ & $\mathbf{f} \%$ & Kategori \\
\hline $10-15$ & 0 & 0 & $\begin{array}{c}\text { Sangat } \\
\text { rendah }\end{array}$ \\
& & & Rendah \\
$16-21$ & 10 & 3,5 & Sedang \\
$22-27$ & 143 & 49,7 & Tinggi \\
$28-33$ & 97 & 33,7 & Sangat \\
$34-40$ & 38 & 13,2 & Tinggi \\
\hline Total & 288 & 100 & \\
\hline
\end{tabular}

Apabila digambarkan dalam bentuk histogram, variabel tingkat motivasi siswa dalam pembelajaran PJOK adalah sebagai berikut:

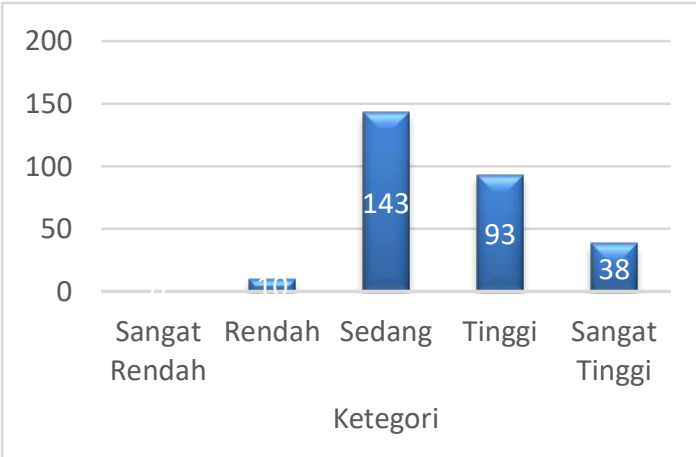

Gambar 1. Tingkat Motivasi Siswa Dalam Mengikuti Pembelajaran PJOK di SMAN 2 Sumenep

Dari tabel dan gambar di atas diketahui bahwa tidak ada siswa pada kategori sangat rendah. Selanjutnya diketahui pada kategori rendah sebanyak 10 siswa, pada kategori sedang sebanyak 143 siswa, pada kategori tinggi sebanyak 93 siswa, dan pada kategori sangat tinggi sebanyak 38 siswa. Berdasarkan tabel dan gambar di atas dapat disimpulkan bahwa sebagian besar tingkat motivasi siswa dalam mengikuti pembelajaran PJOK berada pada kategori sedang yaitu 143 (49,7\%) siswa.

Deskripsi Jawaban Model Aktivtas Jasmani Siswa dan Guru SMAN 2 Sumenep di Masa Pandemi.

Model aktivitas jasmani siswa dan guru SMAN 2 Sumenep dimasa pandemi dilakukan dengan pemanfaatkan teknologi berupa internet yang mudah di akses oleh siswa seperti Jurnal Ilmiah Mandala Education
WhastApp, Telegram, google classroom dan Vidio Zoom. Berikut gambaran dari model aktivitas jasmani siswa dan guru SMAN 2 Sumenep dimasa pandemi dengan setiap pernyataan sesuai opsi jawaban yaitu: “(1) tidak pernah", “(2) jarang”, "(3) sering” dan "(4) selalu".

Di masa pandemi, aktivitas jasmani diisi dengan tugas mengerjakan latihan soal yang telah di siapkan oleh guru PJOK melalui google classroom.

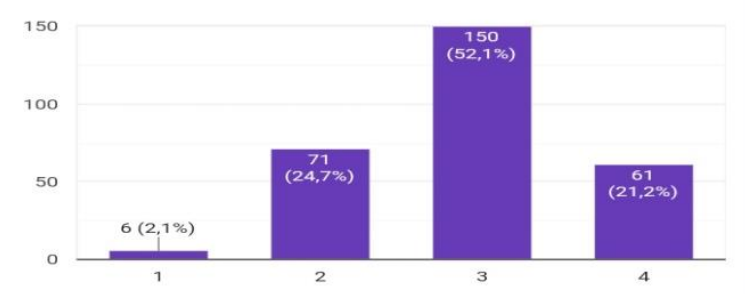

Gambar 2. Model Aktivitas Pembelajaran PJOK Dengan Tugas Melalui Google Classrom

Di masa pendemi, aktivitas jasmani diisi dengan menyimak vidio pembelajaran lewat YouTube yang telah dibuat oleh guru PJOK kemudian didiskusikan bersama-sama melalui kolom komentar.

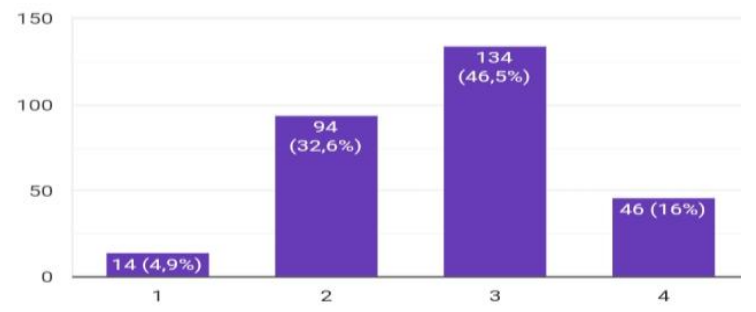

Gambar 3. Model Aktivitas Pembelajaran PJOK Dengan Mengakses Vidio Melalui YouTube

Di masa pandemi, siswa diminta membuat vidio dokumenter melakukan aktivitas jasmani secara mandiri dari rumah yang kemudian dikirim melalui WhatsApp, Telegram.

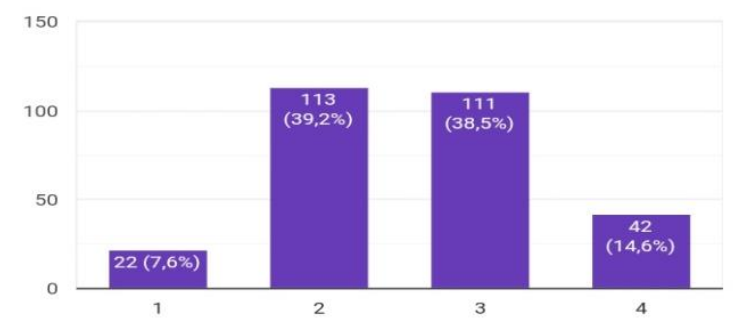

Gambar 4. Model Aktivitas Pembelajaran PJOK Dengan Membuat Vidio Dokumenter 
Di masa pandemi, siswa diperintahkan untuk belajar melalui e-book kemudian merangkumnya dan diserahkan ke guru PJOK melalui WhastApp, Telegram.

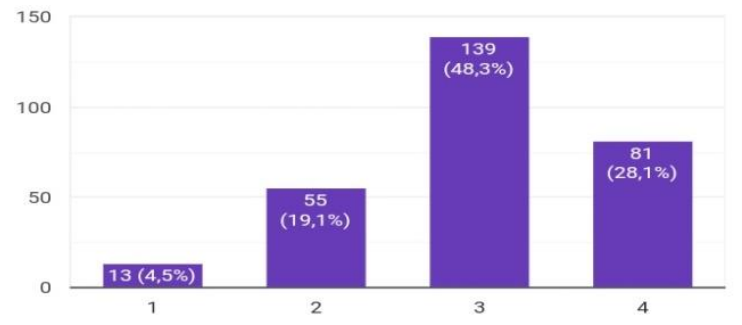

Gambar 5. Model Aktivitas Pembelajaran PJOK Dengan Tugas Mandiri Melalui $e$-book

Di masa pandemi, aktivitas jasmani di isi dengan kegiatan pemanasan berSama menggunakan vidio Zoom.

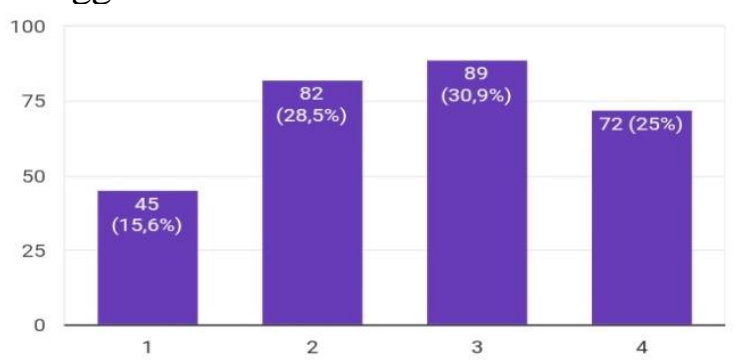

Gambar 6. Model Aktivitas Jasmani Dengan Pemasanan Bersama Melalui Zoom

Di masa pandemi, aktivitas jasmani di isi dengan berbagai materi/teori PJOK dengan menggunakan vidio Zoom.

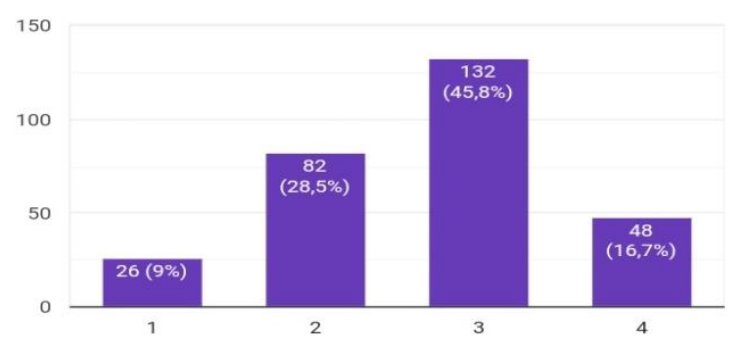

Gambar 7. Model Aktivitas Pembelajaran

PJOK Dengan Materi/Teori Melalui Zoom

\section{PEMBAHASAN}

Penelitian ini bertujuan untuk mengetahui tingkat motivasi siswa dalam mengikuti pembelajaran PJOK dan model aktivitas jasmani siswa dan guru SMAN 2 Sumenep di masa pandemi. Instrumen yang digunakan dalam penelitian ini untuk memperoleh data primer adalah dengan menggunakan angket (google form) yang terdiri dari 10 aitem pernyataan untuk tingkat motivasi siswa dalam mengikuti pembelajaran PJOK dan 6 aitem pernyataan untuk model aktivitas jasmani siswa dan guru SMAN 2 Sumenep. Selanjutnya peneliti menggunakan uji Validitas dan Reliabilitas, hal ini dilakukan untuk mengetahui valid tidaknya serta reliabel atau tidaknya angket yang akan dijadikan tolak ukur untuk mengukur tingkat motivasi siswa dalam mengikuti pembelajarn PJOK dan model aktivitas jasmani siswa dan guru SMAN 2 Sumenep di masa pandemi.

\section{Tingkat Motivasi Siswa Dalam Mengikuti Pembelajaran PJOK di Masa Pandemi.}

Berdasarkan hasil penelitian yang telah dilakukan di SMAN 2 Sumenep dengan jumlah sampel 288 siswa yang terdiri dari kelas X sebanyak 103 siswa, kelas XI sebanyak 79 siswa dan kelas XII sebanyak 106 siswa, diketahui bahwa tingkat motivasi siswa dalam mengikuti pembelajaran PJOK di masa pandemi yang pelaksanaanya dilakukan secara on-line ada pada kagetori sedang. Dari hasil penelitian ini dapat dipahami bahwa terdapat faktor yang berhubungan dengan tingkat motivasi siswa di SMAN 2 Sumenep dalam mengkuti pembelajaran PJOK di masa pandemi diantaranya adalah sebagai berikut:

\section{Pembelajaran PJOK (BDR)}

Pembelajaran PJOK di masa pandemi yang dilakukan dari rumah sebenarnya membuat pengalaman baru bagi para siswa yang sebelumnya aktivitas tersebut dilakukan di lapangan terbuka (sekolah) saat ini harus dilaksanakan dari rumah dengan menggunakan teknologi internet. Jika dilihat dari dampak positifnya yaitu untuk memutus mata rantai penyebaran covid-19 di Indonesia dan juga dapat memberikan pengalaman baru bagi para siswa serta menjadi ladang kreativitas bagi siswa dan guru PJOK. Akan tetapi, jika dilihat dari dampak negatifnya pembelajaran dari rumah yang dilakukan dalam kurun waktu terlalu lama memberikan dampak psikologis tersendiri bagi para siswa. Seperti halnya siswa merasa bosan atau jenuh yang disebabkan kurangnya interaksi antara siswa dan guru selain itu para siswa hanya mengerjakan tugas latihan yang diinstruksikan oleh guru, maka dari itu tidak 
dapat dipungkiri kalau hal tersebut dapat berhubungan dengan tingkat motivasi siswa. "motivation greatly influences an individual's performance in situations where one is physically capable of performing the task but is uncertain about capabilities, which in many cases is a problem that driver people not to begi with a chosen sports activity (Kodri et al., 2013:10).

2. Berkurangnya interaksi secara langsung antar siswa dan guru.

Siswa yang biasanya berinteraksi langsung di dalam kelas dengan individu lainnya kini diubah peraraturannya, di mana para siswa harus melakukan pembelajaran sendirisendiri dan juga di rumah masing-masing. Karena itulah siswa butuh beradaptasi dengan perubahan ini dan secara otomatis akan mempengaruhi daya serap materi dan motivasi siswa dalam mengikuti pembelajaran PJOK. Karena faktor berkurannya interaksi dan penutupan sekolah yang cukup lama, akhirnya siswa merasa bosan/jenuh dan pada akhirnya dapat memperngaruhi tingkat motivasi siswa dalam mengikuti pembelajaran khususnya pembelajaran PJOK.

3. Mata pelajaran PJOK hanya mata pelajaran sampingan.

Dalam pembelajaran PJOK di sekolah tersebut masih dipandang sebelah mata dan diremehkan oleh para siswa dibandingkan dengan mata pelajaran lainnya, seolah-oleh mata pelajaran ini hanya pengisi waktu luang dan pelengkap saja. Terbukti bahwa dari hasil wawancara yang dilakukan dengan beberapa siswa SMAN 2 Sumenep terlihat bahwa siswa masih menganggap bahwa mata pelajaran PJOK hanya sebagai mata pelajaran biasa yang tidak terlalu penting karena mata pelajaran tersebut tidak diuji nasionalkan. Hal ini merupakan tugas guru PJOK untuk merubah persepsi siswa yang negatif terhadap mata pelajaran PJOK.

4. Model pembelajaran PJOK di masa pandemi

Kegiatan belajar-mengajar di masa pandemi mengharuskan disemua jenjang pendidikan untuk melaksanakan PJJ dengan media online tak terkecuali dengan guru PJOK dalam melaksanakan tugasnya sebagai guru. Pandemi Covid-19 telah menjadi pintu masuk untuk mengubah pembelajaran tekstual menjadi kontekstual. Pembelajaran kontekstual merupakan konsep belajar yang mengaitkan antara materi pelajaran dalam kehidupan sehari-hari. Berdasarkan hasil observasi di SMAN 2 Sumenep bahwa selama pandemi model pembelajaran PJOK dilaksanakan dengan menggunakan aplikasi gratis yang dapat di download oleh siswa berupa Google Classroom, YouTube, WhatsApp dan Telegram sebagai medianya. Alasannya aplikasi ini dianggap sederhana dan mudah digunakan oleh para siswa.

\section{Model Aktivitas Jasmani Siswa dan Guru SMAN 2 Sumenep di Masa Pandemi.}

Jika diamati sebenarnya model aktivitas jasmani yang diterapkan oleh guru kepada siswa di SMAN 2 Sumenep sudah bervariatif, artinya aktivitas pembelajaran tersebut tidak monoton. Berikut beberapa model aktivitas jasmani siswa dan guru SMAN 2 Sumenep di masa pandemi:

Di masa pandemi, aktivitas jasmani diisi dengan tugas mengerjakan latihan soal yang telah di siapkan oleh guru PJOK melalui google classroom, di masa pendemi, aktivitas pembelajaran jasmani diisi dengan menyimak vidio pembelajaran lewat YouTube yang telah dibuat oleh guru PJOK kemudian didiskusikan bersama-sama melalui kolom komentar, di masa pandemi, siswa diminta membuat vidio dokumenter melakukan aktivitas jasmani secara mandiri dari rumah yang kemudian dikirim melalui WhatsApp, Telegram, di masa pandemi, siswa diperintahkan untuk belajar melalui e-book kemudian merangkumnya dan diserahkan ke guru PJOK melalui WhastApp, Telegram, di masa pandemi, aktivitas jasmani di isi dengan kegiatan pemanasan bersama menggunakan Zoom, di masa pandemi, aktivitas jasmani di isi dengan berbagai materi/teori PJOK dengan menggunakan Zoom

Dari beberapa model aktivitas jasmani yang dilakukan oleh siswa dan guru SMAN 2 Sumenep di masa pandemi ternyata opsi jawaban paling banyak adalah dimasa 
pandemi, aktivitas jasmani sering di isi dengan mengerjakan tugas latihan soal yang telah disiapkan melalui google classroom yaitu sebanyak $150(52,1 \%)$ siswa.

\section{KESIMPULAN}

Tujuan dari pelaksanaan penelitian ini adalah untuk memperoleh informasi tingkat motivasi siswa dalam mengikuti mata pelajaran PJOK di masa pandemi dan model aktivitas jasmani yang dilakukan siswa dan guru di masa pandemi. Hasil yang diperoleh dari penelitian ini yaitu tingkat motivasi siswa dalam mengikuti pembelajaran PJOK di masa pandemi berada pada ketegori sedang. Sedangkan model aktivitas jasmani siswa dan guru SMAN 2 Sumenep di masa pandemi dilakukan dengan menggunakan aplikasi gratis berupa Google Classroom, YouTube, Zoom, WhatsApp dan Telegram.

\section{SARAN}

Untuk mencapai tujuan pendidikan nasional, guru harus selalu aktif serta kreativitas dan inovasi dalam menyajikan pembelajaran yang menyenangkan

\section{UCAPAN TERIMA KASIH}

Ucapan terima kasih kepada SMAN 2 Sumenep yang telah memberikan izin sebagai tempat penelitian penulis.

\section{.DAFTAR PUSTAKA}

Anam, S. (2018). Pendidikan Jasmani Olahraga Dan Kesehatan Berbasis Bleded Learning. Seminar Nasional Profesionalisme. 64-72.

Araujo, R., Masquita, I., \& Hastie, P. (2014). Review Of The Status Of Learning In Research On Sport Education. Journal Of Sports Science And Medicine. 13(4), 846-858.

Ferismayanti. (2020). Meningkatkan Motivasi Belajar Siswa Pada Pembelajaran Online Akibat Pandemi. Jornal Sosial Humaniora Terapan Universitas Indonesia 2(2) 1-10.

Gallegos, A. G., Extremera, A. B., Quero, F. J., Chamaco, M. M, \& Amador, C.B.
(2012). Analysis Of Motivation Profiles Of Satisfation And Importance Of Phyisical Education In High Scholl Adolescents. Journal Of Sports Science And Medicine. 11,614-623.

Guvenc, A., Acikada, C., Aslan, A., \& Ozer, K. (2011).Daily Physical Activty And Physical Fitness In 11-To 15-Year-Old Trainet And Untrained Turkish Boys. Journal of Sports Science And Medicine. 10,(3) 502-514.

Glasten, A., Watt, A. (2017). A Motivational Of Physical Education And Links To Enjoyment Knowledge Total Physical Activity And Body Mass Index. Journal of Sports Science And Medicine. 16(3) 318-327.

Huhtinimi, M., Saakslathti, A., Watt, A., Jaakkola, T. (2019). Associations Among Basic Psychological needs Motivation And Enjoyment Within Finnish Physical Education Students. Journal Of Sports Science And Medicine. 19 (2) 239-247.

Ikhwan, T. (2016). Motivasi Siswa Kelas XI Dalam Mengikuti Pembelajaran Pendidikan Jasmani Pada SMA Kota Yogyakarta Tahun 2016. Journal Of Education.8 (2), 2-13.

Kodri, M., Sindik, J., Furjan, G., Schiefler, B. (2013). Participation Motivation And Student's Physical Activity Among Sport Students In Theree Countries. Journal of Sports Science And Medicine. 12(3) 10-18.

Muhaji., \& Santosa, B. (2016). Pendidikan Jasmani Olahraga dan Kesehatan. Jakarta: Kementerian Pendidikan dan Kebudayaan.

Moreno, M. J., Siccilia, A., Cervello, E., Huescar, E., \& Delia, C. (2011). The Relationship Between Goal Orientations Motivational Climate And Reported Discipline In Physical 
Education. Journal Of Sports Science And Medicine. 11(10), 119-129.

Moreno, M. J., Cervello, E., Huescar, E., Rodriguez, J. (2013). Motivational Profiles In Physical Educations And Their Relation To The Theory Of Planned Behavior. Journal of Sports Science And Medicine. 13(12), 551558.

Nurhasanah, S., \& Sobadi, A. (2016). Minat Belajar Sebagai Determinan Hasil Belajar Siswa. Jurnal Pendidikan Manajemen Perkantoran. 1(1), 135142.

Oktavian, K., \& Hariyoko. (2020). Survei Motivasi Peserta Didik Dalam Mengikuti Pembelajaran Pendidikan Jasmani Olahraga Dan Kesehatan Di Sekolah Menengah Pertama. Sport Science And Health 2(2) 114-118.

Purwanto, A, Masduki, R., Budi, S.P., Mayesti, L., Choi Chi H., Setyowati, P. R., (2020). Studi Eksploratif Dampak Pandemi COVID-19 Terhadap Proses Pembelajaran Online Di Sekolah. Journal Of Education Psychology And Counseling. 1 (2) 1-12.

Qomarullah, R. (2015). Model Aktivitas Belajar Gerak Berbasis Permainan Sebagai Materi Ajar Pendidikan Jasmani. Journal Of Physical Education Health And Sport. 2 (2) 7688.

Sitorus, Y. I. (2020). Analisis Motivasi Belajar Siswa Menggunakan Video Animasi Sebagai Alternatif Pembelajaran Jarak Jauh(PJJ) Pada Materi Segitiga Di SMA As'Sadah VII. Journal of Education.8 (2), 100-105.

Sumaryoto, \& Soni. (2017). Pendidikan Jasmani Olahraga Dan Kesehatan. Jakarta: Kementerian Pendidikan dan Kebudayaan.
Soini, M., Luikkonen, J., Watt, A., Yii-Piipari, S., \& Jaakkola, T. (2014). Factorial Validity And Internal Consistency Of The Motivational Climate In Phyisical Education Scale. Journal of Sports Science And Medicine. 13(1), 137-144.

Sriundy, M, I.Made. (2017). Evaluasi Pengajaran. Surabaya: Unesa University Press.

Sriundy, M, I.Made. (2015). Metodelogi Penelitian. Surabaya: Unesa University Press.

Yu-Kai C., Senlin Chen Kun-Wei \& Li-Kang C. (2016). Effect Of Autonomy Support On Self-Determined Motivation In Elementary Physical Education. Journal Of Sports Science And Medicine. 15(1), 460-466.

Wahyu, D. (2020), Dampak Covid-19 Terhadap Implementasi Pembelajaran Daring Di Sekolah Dasar. Jurnal Ilmu Pendidikan 2(1) 55-61.

Widodo. (2014). Stategi Peningkatan Aktivitas Jasmani Siswa Sekolah Dasar Di Luar Pembelajaran Pendidikan Jasmani Olahraga Dan Kesehatan Di Indonesia. Jurnal Pendidikan Dan Kebudayaan. Jurnal Ilmu Pendidikan 2 (2) 81-94.

https://id.wikipedia.org/wiki/Pandemi di akses 21 agustus pada jam 07.08 WIB 